\title{
小説の進行を特徵づける指標としての動詞生起頻度
}

\section{Verb frequencies as indices of story progression}

\author{
工藤彰1*, 村井源 ${ }^{1}$, 徃住彰文 ${ }^{1}$ \\ Akira KUDO, Hajime MURAI, Akifumi TOKOSUMI
}

\author{
*1 東京工業大学大学院社会理工学研究科 \\ Graduate School of Decision Science and Technology, Tokyo Institute of Technology \\ 干152-8552 東京都目黒区大岡山2-21-1 \\ E-mail: \{akudo,h_murai,akt\}@valdes.titech.ac.jp
}

小説が進行するに従って, 様々な表現の性質は変化していくものである. 本研究の目的は用いら れた動詞の観点から小説展開を計量的に特徵づけることである. 具体的には, 異なる主人公と物語 の奇数章と偶数章からなる村上春樹の並行形式小説『1Q84』を対象とし, キャラクターの行為の指標 として動詞の出現頻度を分析する. 二組のチャプター群をそれぞれ六つのパートに分割後, 全ての 文章をキャラクターに関連のあるアクションを示す動詞を特定するため機械的に構文解析し, 統計分 析によって体系的傾向を持つ五つの動詞を明らかにした. 本研究では, 特定のアクションを示す動 詞の相対的頻度の推移は, 奇数章 (動から静) と偶数章 (静から動)の対照的な傾向に影響されてい ると論じた.

As a story progresses, various expressive aspects may change. The aim of this study is to quantitatively characterize story progression in terms of the verbs employed. Specifically, we target Haruki MURAKAMI's “1Q84", with its parallel novel format novel where odd-numbered and even-numbered chapters have different protagonists and stories, and analyze verb occurrences as indices of character behavior. The two sets of chapters were divided into six parts and whole sentences were automatically parsed to identify the action verbs associated with the characters. Statistical analysis revealed five verbs that have systematic tendencies. Within the odd-numbered chapters, interpersonal actions decrease and mental actions increase, while interpersonal actions increase within the even-numbered chapters. The paper argues that shifts in the relative frequencies of certain action verbs are reflected in the contrastive moods of the odd-numbered chapters (from active to still) and even-numbered chapters (from still to active).

キーワード:文学, 村上春樹, 並行形式小説, 係り受け関係, 動詞生起頻度, 小説進行

Literature, Haruki MURAKAMI, Novels in Parallel Format, Modification Relation, Verb Frequencies, Story Progression 


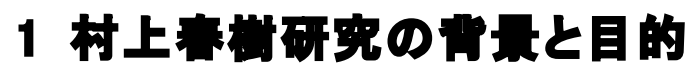

現代日本文学を代表する作家の一人村上 春樹は長・短篇やエッセイ, 翻訳等多産な執 筆活動で知られるが, 近年は日本国外でフラ ンツ・カフカ賞, フランク・オコナー国際短 篇賞, エルサレム賞の受賞と国際的理解が高 まっている. その一方, まだ村上の持ち得た 文学性や普遍性の解明については充分に論 じ尽くされていない.

村上については人文学的手法で研究が既 に多数なされているが, 計量的手法の導入で より網羅的に分析可能でかつ新しい論点も 発見されている.たとえば村上の作風変化に ついては黒古[1]のようにオウム事件と阪神 大震災のあった1995年に転向の契機を読み 取る主張が一般に多いが, 計量的手法を用い た工藤ら [2]のクラスタ分析においても，作 風の第二の変化の時期として1995年がそれ に当たることを実証し, 同時に第一の変化の 時期が初期三部作と中期作品群の間に存在 することを発見している。

本研究で扱う長篇小説『1Q84』は奇数章 (青 豆）と偶数章 (天吾) で主人公が入れ替わる 形式で書かれており, 当初の関係性の見えに くさが次第に一つの物語に収斂していく小 説である．村上には他にも『世界の終りと八 ードボイルド・ワンダーランド』や『海辺の カフカ』等の並行形式の小説があるが，一見 無関係に並行して進行する二重の物語を時 系列で分析することにより, その関連性の変 化が認識可能となる.これは村上文学の構築 を理解する上で重要であると思われる.

また手法としては小説内のキャラクター (登場人物) とアクション（行動）に着目し た係り受け分析から物語内容の特徽を明ら かにし，時系列によってキャラクターとアク
ションのパターンに変化が現れるかどうか 計量的に俯瞰可能にすることを目的とする. これまで登場人物と行動の関係を考察した 物語論に物語を連辞的に固定した諸機能の 連鎖と考えたプロップ[3]のロシア魔法民話 の分析や, 物語の行為者を主体/対象, 送り 手/受け手, 援助者/反対者に分類したグレマ ス [4]の行為項モデルなどがあるが，作家や ジャンルに左右されないテキストを対象に, 近年計量書誌学の領域で発展を遂げてきて いる大規模な解析を念頭に措くと, 現状では テキストの語彙に基づいた定量性によって 客観性を担保し, 従来の物語論が獲得してき た知見を参照しながら, 計量分析の精度や可 能性を探っていくことに意義があるように 思われる。

風丸[5]は『1Q84』について, B00K1終盤か らからB00K2のほぼ全体を占める青豆のリー ダー殺しのエピソードは, プロップの民話分 析の第九から第二十三機能に該当し, 一方, 天吾の物語は主体と客体が入れ替わりなが ら延々と「交渉」の反復が行われていると指 摘する. 青豆の物語は行為の直線的な連鎖か ら成り立っており「機能的」であるが，天吾 の物語は同じ行為パターンが何度もリピー トされ天吾の心的作用に次々に接続してお り「指標的」だと両章について分析している.

また工藤ら [6]は『1084』の奇数章と偶数 章の名詞の差異を計量的に示しそれぞれの 特徵を挙げているが, 本研究は係り受け分析 と時系列による推移に着目することで, 客観 的な語彙の頻度に基づいた物語のよりダイ ナミックな変動を捉えることが期待できる.

\section{2 対衰となるデータ}

使用したのは『1Q84』のB00K1，2，3で， BOOK 1 の奇数章前半 (1～11章) を青豆 1 , 後 
半 (13～23章) を青豆 2 , 偶数章前半 ( $2 \sim 12$ 章) を天吾1，後半（14～24章）を天吾2, B00K2 の奇数章前半（1～11章）を青豆 3 , 後半 (13 ～23章) を青豆 4 , 偶数章前半 ( $2 \sim 12$ 章) を天 吾3, 後半（14〜24章）を天吾4とした.また B00K3では牛河という第三の語り手を持つ章 があるが, 今回は青豆と天吾の章のみを採用 し，青豆5（2，5，8，11，14章），青豆6（17， $20 ， 23 ， 26 ， 29$ 章) , 天吾5 $(3,6 ， 9 ， 12$, 15章), 天吾 $6(18 ， 21 ， 24 ， 27 ， 30$ 章) とし た。 その基礎統計值が表1である。語数の多 さはB00K2まで天吾 1 ，青豆 2 ，天吾3，青豆4 と交互に変化したが, B00K3は一定して天吾5,

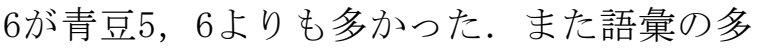
さは青豆 $1,2,4$ と天吾 $3,5,6$ 半々だったが, 語数の平均文長は全て天吾の方が長かった。

表 1 『1Q84』の基礎統計値

\begin{tabular}{|c|c|ccc|}
\hline 巻数 & パート & 語数 & 語彙数 & 平均文長 \\
\hline \multirow{2}{*}{ BOOK1 } & 青豆1 & 47886 & 5178 & 15.4 \\
& 青豆2 & 54271 & 5067 & 15.5 \\
\multirow{2}{*}{ BOOK2 } & 青豆3 & 48159 & 4346 & 14.8 \\
& 青豆4 & 49707 & 4397 & 14.7 \\
\multirow{2}{*}{ BOOK3 } & 青豆5 & 31120 & 3361 & 14.5 \\
& 青豆6 & 27589 & 2936 & 14.8 \\
\hline \multirow{2}{*}{ BOOK1 } & 天吾1 & 57029 & 5073 & 15.6 \\
& 天吾2 & 50464 & 4987 & 15.6 \\
\multirow{2}{*}{ BOOK2 } & 天吾3 & 53552 & 4780 & 15.9 \\
& 天吾4 & 39896 & 3772 & 15.8 \\
\multirow{2}{*}{ BOOK3 } & 天吾5 & 42073 & 4117 & 15.1 \\
& 天吾6 & 35510 & 3674 & 15.4 \\
\hline
\end{tabular}

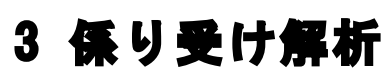

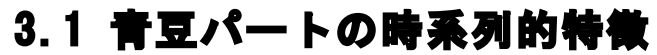

青豆1～6に登場する「青豆」と動詞（自立） に係り受け解析を行った上位語が表2である. 上位三位までの「言う」「する」「思う」に 変化はなかったが，青豆1，2で次に多かった

「尋ねる」は次第に減少傾向にあった．青豆
1，2，3に多い「肯く」も同様，徐々に減る 傾向にあった．青豆1〜 5まで $2 \%$ 以上の割合 の「振る」も青豆 6 では $0.58 \%$ と減少した。 また「できる」は後半に増える傾向にあり， 青豆 $4 ， 5$ で特に多かった。「わかる」も後半 に多く，特に青豆 $4 ， 5 ， 6 て ゙ 1.5 \%$ 以上の割合 を見せた。

\subsection{1 青豆パートの考戠}

まず青豆1，2で多かった「尋ねる」である が，テキスト中では青豆が疑問を感じた際， 字義通り用いられていた。物語の序盤に謎や 問題が提起され，それに対処していく行動の 一つと考えられる。 B00K3の青豆5，6で減少 しているのは, 物理上, 一人で部屋の中に留 まっているシーンが続くために「尋ねる」相 手がいなかったことが挙げられるだろう。

また同様減少した「肯く」は肯定を示す動 詞として用いられており, 青豆1４（B00K1，

2）では相桘の動作として使われていたが, これも青豆5，6(B00K3) では孤独の時間が続 くため減少傾向にあった. 前半で積極的に外 部と接触するが後半でその機会が失われた ことが見てとれた。

「振る」は，「青豆は首を振った」のように 否定の象徵的行為として用いられており, 工 藤ら [7]の村上初期三部作の分析に見られた

「鼠」というキャラクターの「振る」という 使われ方と一致した。青豆6のみで大きく減 っているのは彼女の目的である天吾との再 会という前向きな気持ちが否定の身振りを 遠ざけたためと思われる。

「できる」は可能を示す動詞として用いられ ており，青豆4，5で急激に増えているのは，

「さきがけ」リーダーの殺害とそこからの逃 亡，そして己の身を隠すこと，という任務を 遂行するにあたって「青豆は手足を動かすこ とができない」のような自身の能力を問われ 
表 2 青豆の係り受け語 上位語

\begin{tabular}{|c|c|c|c|c|c|c|c|c|c|c|c|c|c|c|c|c|c|}
\hline 青豆1 & 回数 & 割合 & 青豆2 & 回数 & 割合 & 青豆3 & 回数 & 割合 & 青豆4 & 回数 & 割合 & 青豆5 & 回数 & 割合 & 青豆6 & 回数 & 割合 \\
\hline 言う & 55 & $17.30 \%$ & 言う & 104 & $30.68 \%$ & 言う & 83 & $23.92 \%$ & 言う & 61 & $22.18 \%$ & 言う & 37 & $20.90 \%$ & 言う & 44 & $25.43 \%$ \\
\hline する & 41 & $12.89 \%$ & する & 24 & $7.08 \%$ & する & 38 & $10.95 \%$ & する & 29 & $10.55 \%$ & する & 24 & $13.56 \%$ & する & 23 & $13.29 \%$ \\
\hline 思う & 27 & $8.49 \%$ & 思う & 22 & $6.49 \%$ & 思う & 24 & $6.92 \%$ & 思う & 27 & $9.82 \%$ & 思う & 15 & $8.47 \%$ & 思う & 18 & $10.40 \%$ \\
\hline 尋ねる & 14 & $4.40 \%$ & 尋ねる & 22 & $6.49 \%$ & 肯く & 12 & $3.46 \%$ & できる & 11 & $4.00 \%$ & できる & 6 & $3.39 \%$ & わかる & 8 & $4.62 \%$ \\
\hline 見る & 10 & $3.14 \%$ & 肯く & 14 & $4.13 \%$ & 見る & 11 & $3.17 \%$ & わかる & 7 & $2.55 \%$ & しかめる & 5 & $282 \%$ & 見る & 4 & $2.31 \%$ \\
\hline 肯く & 9 & $2.83 \%$ & $x$ & 8 & $2.36 \%$ & 尋ねる & 11 & $3.17 \%$ & 振る & 6 & $2.18 \%$ & 答える & 5 & $2.82 \%$ & 考える & 4 & $2.31 \%$ \\
\hline 振る & 8 & $2.52 \%$ & 振る & 7 & $2.06 \%$ & 振る & 7 & $2.02 \%$ & $x$ & 5 & $1.82 \%$ & 考える & 4 & $2.26 \%$ & 戻る & 3 & $1.73 \%$ \\
\hline しかめる & 7 & $2.20 \%$ & 見る & 7 & $2.06 \%$ & なる & 7 & $2.02 \%$ & 尋ねる & 5 & $1.82 \%$ & 振る & 4 & $2.26 \%$ & 座る & 3 & $1.73 \%$ \\
\hline 知る & 6 & $1.89 \%$ & なる & 6 & $1.77 \%$ & できる & 6 & $1.73 \%$ & かける & 4 & $1.45 \%$ & 告げる & 3 & $1.69 \%$ & なる & 3 & $1.73 \%$ \\
\hline 感゙る & 5 & $1.57 \%$ & 考える & 5 & $1.47 \%$ & しかめる & 5 & $1.44 \%$ & 肯く & 4 & $1.45 \%$ & わかる & 3 & $1.69 \%$ & できる & 3 & $1.73 \%$ \\
\hline 待つ & 4 & $1.26 \%$ & 眺める & 5 & $1.47 \%$ & い & 4 & $1.15 \%$ & 知る & 4 & $1.45 \%$ & 守る & 3 & $1.69 \%$ & 知る & 3 & $1.73 \%$ \\
\hline 考える & 4 & $1.26 \%$ & 出る & 4 & $1.18 \%$ & 泣く & 4 & $1.15 \%$ & い & 3 & $1.09 \%$ & 知る & 3 & $1.69 \%$ & 送る & 2 & $1.16 \%$ \\
\hline とる & 4 & $1.26 \%$ & わかる & 4 & $1.18 \%$ & 飲む & 4 & $1.15 \%$ & 見つめる & 3 & $1.09 \%$ & 出す & 3 & $1.69 \%$ & 認める & 2 & $1.16 \%$ \\
\hline わかる & 4 & $1.26 \%$ & いる & 4 & $1.18 \%$ & 受け取る & 4 & $1.15 \%$ & 噛む & 3 & $1.09 \%$ & あてる & 2 & $1.13 \%$ & 閉じる & 2 & $1.16 \%$ \\
\hline 乗る & 4 & $1.26 \%$ & 思い出す & 4 & $1.18 \%$ & 立ち上がる & 3 & $0.86 \%$ & 感じる & 3 & $1.09 \%$ & 出る & 2 & $1.13 \%$ & 眺める & 2 & $1.16 \%$ \\
\hline なる & 4 & $1.26 \%$ & ある & 4 & $1.18 \%$ & 手渡す & 3 & $0.86 \%$ & やる & 3 & $1.09 \%$ & 澄む & 2 & $1.13 \%$ & いる & 2 & $1.16 \%$ \\
\hline できる & 4 & $1.26 \%$ & 驚く & 3 & $0.88 \%$ & 従う & 3 & $0.86 \%$ & 失う & 3 & $1.09 \%$ & 求める & 2 & $1.13 \%$ & 思い浮かべる & 2 & $1.16 \%$ \\
\hline 探す & 3 & $0.94 \%$ & 感じる & 3 & $0.88 \%$ & 待つ & 3 & $0.86 \%$ & 気づく & 3 & $1.09 \%$ & 待つ & 2 & $1.13 \%$ & やる & 2 & $1.16 \%$ \\
\hline 向ける & 3 & $0.94 \%$ & 置< & 3 & $0.88 \%$ & 感じる & 3 & $0.86 \%$ & 見る & 3 & $1.09 \%$ & 引 & 2 & $1.13 \%$ & 決める & 2 & $1.16 \%$ \\
\hline 微笑む & 3 & $0.94 \%$ & 飲む & 3 & $0.88 \%$ & 気づく & 3 & $0.86 \%$ & 見上げる & 3 & $1.09 \%$ & 外す & 2 & $1.13 \%$ & 尋ねる & 2 & $1.16 \%$ \\
\hline 出す & 3 & $0.94 \%$ & しかめる & 3 & $0.88 \%$ & 繰り返す & 3 & $0.86 \%$ & しかめる & 3 & $1.09 \%$ & $x$ & 2 & $1.13 \%$ & 立つ & 2 & $1.16 \%$ \\
\hline 答える & 3 & $0.94 \%$ & 知る & 3 & $0.88 \%$ & 下ろす & 3 & $0.86 \%$ & なる & 3 & $1.09 \%$ & 行< & 2 & $1.13 \%$ & 㷊る & 2 & $1.16 \%$ \\
\hline 求める & 3 & $0.94 \%$ & & & & 閉じる & 3 & $0.86 \%$ & 言い聞かせる & 3 & $1.09 \%$ & 入る & 2 & $1.13 \%$ & & & \\
\hline 覚える & 3 & $0.94 \%$ & & & & わかる & 3 & $0.86 \%$ & & & & ある & 2 & $1.13 \%$ & & & \\
\hline 思い出す & 3 & $0.94 \%$ & & & & 渡す & 3 & $0.86 \%$ & & & & 置く & 2 & $1.13 \%$ & & & \\
\hline 降りる & 3 & $0.94 \%$ & & & & 默る & & $0.86 \%$ & & & & 気づく & 2 & $1.13 \%$ & & & \\
\hline & & & & & & & & & & & & なる & 2 & $1.13 \%$ & & & \\
\hline & & & & & & & & & & & & 戻す & 2 & $1.13 \%$ & & & \\
\hline
\end{tabular}

表 3 天吾の係り受け語 上位語

\begin{tabular}{|c|c|c|c|c|c|c|c|c|c|c|c|c|c|c|c|c|c|}
\hline 天吾1 & 回数 & 割合 & 天吾2 & 回数 & 割合 & 天吾3 & 回数 & 割合 & 天吾4 & 回数 & 割合 & 天吾5 & 回数 & 割合 & 天吾6 & 回数 & 割合 \\
\hline 該う & 81 & $20.82 \%$ & 訳 & 76 & $22.89 \%$ & 訳 & 78 & $19.21 \%$ & 該う & 57 & $16.29 \%$ & 訳 & 69 & $18.70 \%$ & 訪う & 65 & $29.15 \%$ \\
\hline する & 51 & $13.11 \%$ & する & 40 & $12.05 \%$ & する & 35 & $8.62 \%$ & する & 46 & $13.14 \%$ & する & 49 & $13.28 \%$ & する & 35 & $15.70 \%$ \\
\hline 尋疗る & 22 & $5.66 \%$ & 思う & 16 & $4.82 \%$ & 思う & 28 & $6.90 \%$ & 思う & 44 & $12.57 \%$ & 思う & 24 & $6.50 \%$ & 思j & 13 & $5.83 \%$ \\
\hline 思う & 19 & $4.88 \%$ & 尋ねる & 15 & $4.52 \%$ & 尋ねる & 19 & $4.68 \%$ & 尋ねる & 15 & $4.29 \%$ & 考える & 11 & $2.98 \%$ & 尋ねる & 10 & $4.48 \%$ \\
\hline わかる & 15 & $3.86 \%$ & 考える & 13 & $3.92 \%$ & わかる & 16 & $3.94 \%$ & できる & 13 & $3.71 \%$ & 尋ねる & 11 & $2.98 \%$ & わかる & 8 & $3.59 \%$ \\
\hline できる & 12 & $3.08 \%$ & なる & 12 & $3.61 \%$ & 見る & 12 & $2.96 \%$ & 考える & 10 & $2.86 \%$ & なる & 10 & $2.71 \%$ & 考える & 6 & $2.69 \%$ \\
\hline 考える & 8 & $2.06 \%$ & できる & 10 & $3.01 \%$ & なる & 9 & $2.22 \%$ & わかる & 10 & $2.86 \%$ & 知る & 10 & $2.71 \%$ & やる & 4 & $1.79 \%$ \\
\hline 見る & 8 & $2.06 \%$ & 感しる & 8 & $2.41 \%$ & できる & 8 & $1.97 \%$ & 思い出す & 10 & $2.86 \%$ & 見る & 10 & $2.71 \%$ & できる & 4 & $1.79 \%$ \\
\hline 書き直す & 7 & $1.80 \%$ & 見る & 8 & $2.41 \%$ & ある & 8 & $1.97 \%$ & なる & 9 & $2.57 \%$ & わかる & 8 & $2.17 \%$ & 肯〈 & 4 & $1.79 \%$ \\
\hline 眺め万 & 7 & $1.80 \%$ & わかる & 8 & $2.41 \%$ & $x$ & 8 & $1.97 \%$ & 見る & 7 & $2.00 \%$ & 眺める & 8 & $2.17 \%$ & いる & 4 & $1.79 \%$ \\
\hline 振る & 6 & $1.54 \%$ & $x$ & 7 & $2.11 \%$ & 知る & 7 & $1.72 \%$ & $x$ & 6 & $1.71 \%$ & できる & 6 & $1.63 \%$ & 振る & 3 & $1.35 \%$ \\
\hline 感沉 & 6 & $1.54 \%$ & 知了 & 4 & $1.20 \%$ & やる & 6 & $1.48 \%$ & 飭屯 & 5 & $1.43 \%$ & 肯〈 & 6 & $1.63 \%$ & 向かう & 3 & $1.35 \%$ \\
\hline 知了 & 6 & $1.54 \%$ & 振る & 3 & $0.90 \%$ & 考える & 5 & $1.23 \%$ & 眺める & 5 & $1.43 \%$ & か十る & 6 & $1.63 \%$ & 眺める & 3 & $1.35 \%$ \\
\hline$x$ & 6 & $1.54 \%$ & 置人 & 3 & $0.90 \%$ & 振る & 5 & $1.23 \%$ & 見つめる & 4 & $1.14 \%$ & 感岒る & 6 & $1.63 \%$ & 答える & 3 & $1.35 \%$ \\
\hline 肯〈 & 5 & $1.29 \%$ & 読む & 3 & $0.90 \%$ & 感しる & 5 & $1.23 \%$ & ある & 3 & $0.86 \%$ & 思㤕す & 6 & $1.63 \%$ & なる & 2 & $0.90 \%$ \\
\hline 思い出す & 5 & $1.29 \%$ & 思い出せる & 3 & $0.90 \%$ & 思い出す & 5 & $1.23 \%$ & 抱〈 & 3 & $0.86 \%$ & 戻る & 5 & $1.36 \%$ & 飲む & 2 & $0.90 \%$ \\
\hline 置人 & 4 & $1.03 \%$ & ある & 3 & $0.90 \%$ & 持つ & 5 & $1.23 \%$ & しれる & 3 & $0.86 \%$ & 振る & 4 & $1.08 \%$ & 默る & 2 & $0.90 \%$ \\
\hline 飲む & 4 & $1.03 \%$ & 戻す & 3 & $0.90 \%$ & 眺め万 & 5 & $1.23 \%$ & 知る & 3 & $0.86 \%$ & 飭む & 4 & $1.08 \%$ & 出る & 2 & $0.90 \%$ \\
\hline 待つ & 4 & $1.03 \%$ & 気に二入る & 3 & $0.90 \%$ & 絸诂 & 4 & $0.99 \%$ & 気づく & 3 & $0.86 \%$ & 繰叫返す & 4 & $1.08 \%$ & 替える & 2 & $0.90 \%$ \\
\hline 驚 & 4 & $1.03 \%$ & 書人 & 3 & $0.90 \%$ & 待つ & 4 & $0.99 \%$ & 感污 & 3 & $0.86 \%$ & いる & 4 & $1.08 \%$ & 見る & 2 & $0.90 \%$ \\
\hline 默る & 4 & $1.03 \%$ & 気がく & 3 & $0.90 \%$ & 読む & 4 & $0.99 \%$ & 待つ & 3 & $0.86 \%$ & 切る & 3 & $0.81 \%$ & 感しる & 2 & $0.90 \%$ \\
\hline 眠了 & 4 & $1.03 \%$ & & & & 絽)返す & 4 & $0.99 \%$ & 見上げる & 3 & $0.86 \%$ & 抱 & 3 & $0.81 \%$ & $x$ & 2 & $0.90 \%$ \\
\hline 向かう & 3 & $0.77 \%$ & & & & 失j & 4 & $0.99 \%$ & & & & 入れる & 3 & $0.81 \%$ & 思い出す & 2 & $0.90 \%$ \\
\hline 続统 & 3 & $0.77 \%$ & & & & 答える & 4 & $0.99 \%$ & & & & 送了 & 3 & $0.81 \%$ & 渡す & 2 & $0.90 \%$ \\
\hline なる & 3 & $0.77 \%$ & & & & & & & & & & 行 & 3 & $0.81 \%$ & & & \\
\hline ある & 3 & $0.77 \%$ & & & & & & & & & & & & & & & \\
\hline
\end{tabular}


る瞬間が増えたからだといえる。

「わかる」は理解を示寸動詞として使われて おり後半に増加した理由としては, 天吾との 再会という問題の解決が物語の後半に割り 当てられており, 明るみになってくる事態に 対して，「体内で続いている激しい感情的な 対流を，どのように鎮めればいいのか，青豆 にはわからなかった」のように，青豆にとっ て理解できること/できないことが後半の 孤独な内省の時間に次々生起したためだと 考えられる。

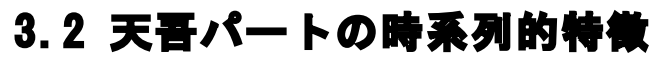

同様，天吾1～6の「天吾」と動詞（自立） に係り受け解析を行った上位語が表3である. 上位2位まで「言う」「する」は共通で，3 位が天吾1のみ「尋衫る」でそれ以外は「思 う」だった。また「肯く」は天吾5，6で，「思 い出す」は天吾4で高い割合を占めた. 天吾1 で「書き直す」が多いがそれ以降はあらわれ ず, 天吾 2 とに「書く」があるのみとなった。

\subsection{1 天要パートの者案}

天吾1のみで「尋㸚る」が3位と多いのは， 青豆同様, 序盤で提示される問題に対処し対 話する場面が比較的多いためと考えられる.

「肯く」が後半で多いのは医者や看護婦や弁 護士などの人物との接触が増え, それに比例 し会話の反応で「肯く」が増えているためと 思われる. 物語の後半になって, 天吾が前半 には見ることのなかった外の新しい世界に 触れていることがここから類推できる.

「思い出す」は天吾4で特に多いが, 字義通 り過去を振り返る行為を示す動詞として使 われており, 特に物語展開にとって重要なこ とを「思い出す」ことが多い。これは物語が 急速に収斂していくきっかけを作者が与え ているクライマックスの場面とも考えられ， B00K2が2009年の刊行時点では結末として想
定されていた根拠の一つとも考えられる.

「書き直す」は天吾1のみで多いが，これは 小説『空気さなぎ』のゴーストライターとし て物語に巻き込まれていく天吾パートの独 自性を明確に打ち出すためと思われる。

\section{3 辛豆パートと天栗パートの比袮}

両章ともに「言う」「する」「思う」が上 位を占めたが, 共通して前半で多かった「尋 ねる」は奇数章のみ後半に向かい減少した。

また奇数章の特徴として「しかめる」が目 立った. 偶数章の特徴としては，「書き直す」 「書く」が前半にあるほか，「思い出す」が 全体を通して多かった。

\subsection{1 四パートを比蛟した新基}

青豆パートのみで「尋ねる」が減少したの は，前述のとおり青豆 5 ，6こおいて青豆が一 人でマンションに閉じこもり内省する時間 が長いことが決定的に影響しているといえ る.

また青豆パートに特有の「しかめる」は, 顔の造作のいびつさが強調され鼻と口が歪 み, 青豆が別人に豹変するときの仕草だと本 文中に説明されている。 その表情が出るのは 自分ひとりのときか, 気に入らない男を劦す ときである. 青豆の内に秘めた狂気の顕在化 として「しかめる」が用いられていることが ここから読み取れる。

天吾パートの「書き直す」「書く」は，小 説をリライトしている天吾の動作だが, 当然 書いている最中はどこかに移動することが できない. 執筆と思索の静的なイメージが天 吾には付与されているといえる. その意味で はB00K3（天吾5，6）に減少するのも，天吾 が外の世界に移動し他者と関わる物語へと シフトしたからだと思われる。

また「思い出す」も天吾の静的なパーソナ リティに合致しており，記憶を辿ることによ 
つて物語を重層化し自身の眼前の物語と往 復しながら語るスタイルが天吾の章にはあ るといえる。

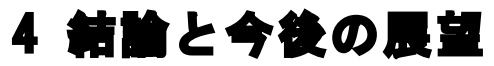

本研究は, 物語進行に従った意味内容の 変遷を解明す心゙く, 村上春樹の並行形式小説 『1Q84』を対象に, 青豆パートと天吾パート のそれぞれを時系列に沿って分割し，登場人 物と動詞による係り受け解析を行った. その 結果，青豆パートは「振る」「肯く」「尋ね る」が減少し「できる」「わかる」が増加， 天吾パートは「肯く」が増加していることが わかった。これらの結果とテキスト中での用 法と照らし合わせると, 前半では青豆と天吾 両方とも自身のパーソナリティ, すなわち青 豆は動的, 天吾は静的な性格を見せていたが, 後半はそれが次第に逆転していく構図が見 て取れたといえる。

今後の展望であるが, 登場人物に着目した 行動パターンとともにチャプターの推移に 従った内容の変化を捉えるため, 一文中での 名詞の共起関係に焦点を当てたい. チャプタ 一の通時的・共時的な機能を計量的に明らか にするという最終的な目標を見据えた上で， 本研究で得られた動詞と今後の名詞の共起 語の結果から, 内容的にどのような相関が見 られるか体系的に明らかにする必要がある。 また村上春樹の他の並行形式小説である『世 界の終りとハードボイルド・ワンダーラン ド』と『海辺のカフカ』の類似や差異を検出, また他の統辞的な物語との比較により, 村上
春樹という作家が想像してきた複雑な物語 の構築モデルの解明が期待される.

\section{期}

本研究は科研費「知識共有のための価值指 向型オントロジーの多分野多言語化」 (20300074) および「レトリカルデータベース システムの構築による計量的修辞分析手法 の確立」（22700256）の助成を受けた.

\section{素文住}

[1] 黒古一夫：『村上春樹「喪失」の物語か ら「転換」の物語へ』, 勉誠出版, 294p. 2007.

［2］工藤彰，村井源，徃住彰文：「計量分 析による村上春樹長篇の関係性と歴史的変 遷」, 情報知識学会誌, Vol.21, No. 1, pp. 18-36, 2011.

[3] ウラジーミル・プロップ：『昔話の形態 学』, 水声社, $385 \mathrm{p} .1987$.

[4]アンジルダス・ジュリアン・グレマス： 『意味について』，水声社，427p. 1992. [5]風丸良彦：『集中講義『1Q84』』，若草 書房, 298p. 2010.

６６］工藤彰, 村井源, 徃住彰文：「村上春 樹の計量的変遷と共時的フィクションの語 彙形成」, IPSJ SIG, Computers and the Humanities Symposium 2010, Vol. 2010, No. 15, pp. 97-102, 2010.

［7］工藤彰，村井源，徃住彰文：「村上春 樹の初期三部作における構造解析」, 情報知 識学会誌, Vol.19, No.2, pp. 126-131, 2009. 